Academic Platform Journal of Engineering and Science

\title{
Ortoper Bulanık Kümelerle Bir Karar Verme Yaklaşımı: Ortoper Bulanık TOPSIS Metodu
}

\author{
${ }^{* 1}$ Elif Doğu \\ ${ }^{1}$ Galatasaray Üniversitesi, Endüstri Mühendisliği Bölümü, Çırağan Cad. No:36 Ortaköy, Beşiktaş, İstanbul, Türkiye, \\ edogu@gsu.edu.tr,
}

Research Paper

Arrival Date: 12.09.2019

Accepted Date: 08.09.2020

Öz

Tıbbi karar verme, son yıllarda mühendisler için önemli bir araştırma alanı haline gelmiştir. Doktorlar daha çok istatistiksel araçlar kullandıklarından, tıbbi kararlarda çok kriterli karar verme modeli kurmak oldukça zordur. Bu noktada bulanık karar destek sistemleri, doktorlara görüşlerini sözel terimlerle ifade etme firsatı sunar. Ortoper bulanık setlerin kullanılması ise karar vericilerin yani doktorların, tereddütlerini ifade etmeleri konusunda bulanık setler arasında en yüksek esnekliği sağlar. Bu çalışmada akut atak şikayeti ile hastaneye başvuran KOAH hastalarının hastane yatış sürelerinin sıralanması için Ortoper Bulanık TOPSIS (OFTOPSIS) metodu önerilmiştir. Bu yöntem doktorların tereddütlerini sözel terimlerle ifade etmede en yüksek esnekliği sağlarken, hastaların durumunu önceden doktorlar tarafından belirlenmiş kriterlere göre değerlendirir. Çalışmanın literature katkısı ilk kez OFTOPSIS metodunu geliştirmek ve tıbbi bir problemde uygulamasını yaparak faydasını göstermektir. Gerçek sıralama ve metot tarafından bulunan sıralama, pozitif bir ilişki varlığını gözlemlemek için Spearman korelasyon katsayısı kullanılarak karşılaştırılmıştır.

Anahtar Kelimeler: Ortoper Bulanık Setler, Çok kriterli karar verme, tıbbi karar verme, hastane yatış süresi

\section{A Decision-Making Approach with Q-Rung Orthopair Fuzzy Sets: Orthopair Fuzzy TOPSIS Method}

\author{
${ }^{* 1}$ Elif Doğu \\ ${ }^{1}$ Galatasaray University, Industrial Engineering Dept., Ciragan Cad. No:36 Ortakoy, Besiktas, Istanbul, Turkey, \\ edogu@gsu.edu.tr
}

\begin{abstract}
Medical decision-making has recently become a crucial research area due to its outputs related to the continuity of human life. Since the physicians used to employ statistical tools for a number of years, constructing a multi-attribute decision framework is quite difficult. In general, fuzzy decision aid systems provide flexibility to the physicians enabling them to express their opinions using linguistic variables. Moreover, orthopair fuzzy numbers allows the decision makers to represent their hesitations while providing linguistic data in both uncertain and hesitant environment. This paper proposes orthopair fuzzy TOPSIS (OFTOPSIS) methodology in order to rank the length of hospital stay of chronic obstructive pulmonary disease patients, who admitted to a chest diseases hospital with an acute exacerbation. The proposed method provides maximum flexibility to the physicians for expressing their hesitations to the system modelers, while assessing patients' status according to pre-determined attributes. The novelty of this paper is to develop OFTOPSIS methodology, and conduct a case study in medical area to demonstrate the robustness of the proposed decision-making framework. The actual ranking and the ranking determined by OFTOPSIS method are compared by Spearman rank correlation coefficient to conclude whether there is a positive relationship between the ranking results.
\end{abstract}

Keywords: q-Rung Orthopair Fuzzy Sets, MADM, Medical Decision-Making, Length of hospital stay, OFTOPSIS

\footnotetext{
${ }^{* 1}$ Corresponding author: Elif Dogu. Galatasaray University, Industrial Engineering Dept., Ciragan Cad. No:36 Ortakoy, Besiktas, Istanbul, Turkey, edogu@gsu.edu.tr, 00902122274480
} 


\section{INTRODUCTION}

Medical decision-making is a challenging research field because of its consequences related to the continuity of human life. The fact that medical doctors are used to working with statistical models also makes it difficult to establish intelligent systems with alternative models. In order to transfer the professional experiences of physicians to mathematical models, researchers are developing unceasingly new tools and techniques. Especially, fuzzy systems and their generalizations created great improvements on this purpose.

Fuzzy sets, developed by Zadeh [1], are powerful instruments in implicating ambiguity and vagueness however, when decision makers prefer to indicate their hesitations on the information that they give, intuitionistic fuzzy sets (IFSs) of Atanassov [2] and pythagorean fuzzy sets (PFS) of Yager [3, 4] become more useful by courtesy of their membership, non-membership and hesitation degree features. In social and medical sciences applications, decision makers tend to demand more freedom and more flexibility while sharing their experiences with mathematical modelers. Therefore, as the most generalized version of the nonstandard fuzzy sets, q-rung orthopair fuzzy sets (q-ROFs) [5] have a serious potential and promise various utilizations.

q-ROFs, mentioned by [5] are relatively novel in the literature. There exist mostly theoretical studies in the last two years. Approximate reasoning with q-ROFs and their basic operations are introduced [6]. Interval-valued q-ROF, which allows decision makers to provide their satisfying degrees and non-satisfying degrees to a given set of alternatives by an interval value, is presented [7]. Exponential operation and aggregation operator for q-ROFs are defined [8]. Orthopair environment is investigated [9]. qROF competition graphs are presented [10]. Correlation coefficient between q-ROFs are introduced [11].

In addition, multiple attribute group decision-making (MAGDM) problems are handled with q-ROFs recently. Linguistic Heronian mean operators [12], Heronian mean operators [13], power Maclaurin symmetric mean operators [14], power partitioned Maclaurin symmetric mean operators [15], Bonferroni mean operators [16], and aggregation operators [14] are introduced. TODIM method is extended with interval valued q-ROFs [17]. Minkowski-type distance measures [18] are presented for distance related MAGDM methods. q-rung picture linguistic sets are proposed [19]. qROFs are also used in green supplier selection problems [19, 20], evaluation of emerging technology commercialization [21], and investment company selection problem [22].

In this study, Technique for Order Preference by Similarity to Ideal Solution (TOPSIS), which is an MADM method proposed by [23], is extended with q-ROFs and the proposed Orthopair Fuzzy TOPSIS (OFTOPSIS) method is applied to a medical decision-making problem. The motivation of the approach is to give decision makers (the physicians) the opportunity to express their hesitations in the most comfortable way while specifying their opinions, and thus to transfer the experiences of the experts to the model in the most comprehensive way possible. Since q-ROFs are the most generalized version of the nonstandard fuzzy sets, they allow physicians to express their hesitation about knowledge in their own way, which adds considerable flexibility to the conventional TOPSIS method. To the best of our knowledge, this paper is the first attempt to define and apply OFTOPSIS methodology. The novelty of this work is the extension of TOPSIS method with q-ROFs, which provide maximum flexibility to decision makers in defining their knowledge and hesitation. The case study is determined as the length of hospital stay prediction of chronic obstructive pulmonary disease (COPD) patients, who admitted to a chest diseases hospital with an acute exacerbation. The objective is to provide to the chest disease specialists maximum flexibility and the convenience of expressing their hesitations, while evaluating patients' status with respect to pre-determined attributes and to determine the discharging order of inpatients. After the discharge of all patients, the actual discharge ranking and the ranking obtained with OFTOPSIS method is compared to observe the performance of the proposed decision support system. Therefore, the contributions of this paper are twofold; proposing the novel OFTOPSIS method and stating its power and applicability in medical decision-making.

The remainder of the paper is organized as follows: Section 2 gives preliminaries of IFSs, PFSs, q-ROFs and reveals the steps of OFTOPSIS methodology. Section 3 provides the numerical application concerning length of hospital stay predictions of COPD patients. Section 4 concludes the study.

\section{MATERIALS AND METHODS}

\subsection{Intuitionistic Fuzzy Sets and Pythagorean Fuzzy Sets}

Intuitionistic Fuzzy Set (IFS) proposed by [2], is an extension of conventional fuzzy sets introduced by [1]. In a finite universe $\mathrm{U}$, an IFS is defined as $I=$ $\left\{\left\langle u, M_{I}(u), N_{I}(u)\right\rangle \mid u \in U\right\}$ where $M_{I}: U \rightarrow[0,1]$ is the degree of membership (degree of satisfaction / belonging), and $N_{I}: U \rightarrow[0,1]$ is the degree of non-membership (degree of dissatisfaction / not belonging) of the element $u \in U$ to the set $I$. For abbreviation, IFSs are represented as $I=$ $\left\langle M_{I}, N_{I}\right\rangle$.

IFSs have an essential constraint on the sum of their degrees of membership and non-membership which is defined as "Strength of commitment of an IFS: $S_{I}(u)=M_{I}(u)+$ $N_{I}(u)$ " by [5].

$$
0 \leq M_{I}(u)+N_{I}(u) \leq 1
$$

The degree of hesitation / indeterminacy (Atanassov's Intuitionistic Fuzzy Index) is defined as

$$
H_{I}(u)=1-S_{I}(u)=1-\left(M_{I}(u)+N_{I}(u)\right)
$$


When $S_{I}(u)=1$, it means $M_{I}(u)=1-N_{I}(u)$ and hence $H_{I}(u)=0$, then $I$ is a conventional fuzzy set. Atanassov's IFSs have a strong feature of allowing a lack in the assignment of membership degrees. In decision-making, it brings important advantages in dealing with the hesitation of the decision makers and lack of information.

Even if the IFSs have an edge on representing human knowledge, they have a binding constraint on the strength of commitment. IFS-type 2 is defined by [4] and referred as Pythagorean Fuzzy Set (PFS) by [3] which is less limiting in acceptable membership degrees and thus more liberating for decision makers and mathematical model constructors. PFSs have the same membership, non-membership and indeterminacy features as IFS; the main difference is in their constraints. Let $P=\left\langle M_{P}, N_{P}\right\rangle_{2}$ be a PFS, then the PFS constraint on $\mathrm{P}$ is

$$
0 \leq M_{P}^{2}+N_{P}^{2} \leq 1
$$

The strength of commitment of $\mathrm{P}$ is defined as $S_{P}=$ $\left(M_{P}^{2}+N_{P}^{2}\right)^{1 / 2}$ and the hesitancy index of $\mathrm{P}$ is defined as $H_{P}=\left(1-S_{P}^{2}\right)^{1 / 2}=\left(1-\left(M_{P}^{2}+N_{P}^{2}\right)\right)^{1 / 2}$.

\section{2. q-Rung Orthopair Fuzzy Sets}

q-Rung Orthopair Fuzzy Set (q-ROF), defined by [5] is the most generalized version of the nonstandard fuzzy sets. $O=$ $\left\langle M_{O}, N_{O}\right\rangle_{q}$ is said to be q-ROF, if it satisfies three conditions:

1) $q$ is greater or equal than 1 .

2) $M_{O} \in[0,1]$ and $N_{O} \in[0,1]$.

3) $0 \leq M_{O}^{q}+N_{O}^{q} \leq 1$.

The strength of commitment of a q-ROF is $S_{O}=$ $\left(M_{O}^{q}+N_{O}^{q}\right)^{1 / q}$ and the hesitancy index of a q-ROF is $H_{O}=$ $\left(1-S_{O}^{q}\right)^{1 / q}=\left(1-\left(M_{O}^{q}+N_{O}^{q}\right)\right)^{1 / q}$. As shown in Fig. 1 , an IFS is a q-ROF with $\mathrm{q}=1$ and a PFS is a $\mathrm{q}-\mathrm{ROF}$ with $\mathrm{q}=2$. The more $q$ increases, the more binding constraint is relaxed which gives decision maker the greatest freedom when $q$ goes to infinity. However, with the same strength of commitment, if q increases, the hesitation degree escalates, which can be interpreted as more uncertainty involvement in the model. It is worth noting that in a decision-making system, it is significant to determine the smallest value of $\mathrm{q}$ to minimize the vagueness.

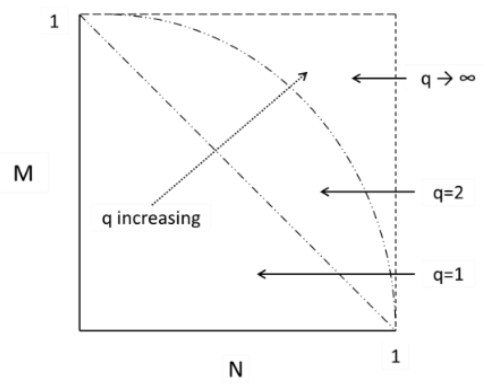

Figure 1. q-ROF membership space [5]
Given two q-ROFS $O_{1}=\left\langle M_{1}, N_{1}\right\rangle_{q}$ and $O_{2}=\left\langle M_{2}, N_{2}\right\rangle_{q}$ and any number $\mathrm{k}$, some basic operations on q-ROFs are given by [24] as follows:

$$
\begin{gathered}
\overline{O_{1}}=\left\langle N_{1}, M_{1}\right\rangle_{q} \\
O_{1} \vee O_{2}=\left\langle\max \left(M_{1}, M_{2}\right), \min \left(N_{1}, N_{2}\right)\right\rangle_{q} \\
O_{1} \wedge O_{2}=\left\langle\min \left(M_{1}, M_{2}\right), \max \left(N_{1}, N_{2}\right)\right\rangle_{q} \\
O_{1} \oplus O_{2}=\left\langle\left(M_{1}^{q}+M_{2}^{q}-M_{1}^{q} M_{2}^{q}\right)^{1 / q}, N_{1} N_{2}\right\rangle_{q} \\
O_{1} \otimes O_{2}=\left\langle M_{1} M_{2},\left(N_{1}^{q}+N_{2}^{q}-N_{1}^{q} N_{2}^{q}\right)^{1 / q}\right\rangle_{q} \\
k O_{1}=\left\langle\left(1-\left(1-M_{1}^{q}\right)^{k}\right)^{1 / q}, N_{1}^{k}\right\rangle_{q} \\
O_{1}^{k}=\left\langle M_{1}^{k},\left(1-\left(1-N_{1}^{q}\right)^{k}\right)^{1 / q}\right\rangle_{q}
\end{gathered}
$$

\subsection{Proposed OFTOPSIS Decision Methodology}

Technique for Order Preference by Similarity to Ideal Solution (TOPSIS), introduced initially by Hwang and Yoon [25], is a tool utilized to solve multi-attribute decisionmaking (MADM) problems. TOPSIS technique aims to identify the closest alternative to the ideal solution, and the farthest one to the anti-ideal solution. The distance to the ideal solution minimizes the benefit and maximizes the cost while the closeness to the ideal solution minimizes the cost and maximizes the benefit. Fuzzy TOPSIS method is an extension of TOPSIS methodology that evaluates criteria and alternatives for solving MADM problems in uncertain environment. The proposed method, named as orthopair fuzzy TOPSIS (OFTOPSIS), enables the decision makers to express their hesitations while providing linguistic data in uncertain as well as hesitant environment. Extension of TOPSIS method with q-ROFs yields maximum flexibility while appealing to expert opinion, with their ability to handle all linguistic terms sets and scales used by the decision makers. This convenience comes from configurable strength of commitment constraint of q-ROFs. In OFTOPSIS method, $\mathrm{q}$ is determined according to the linguistic term sets that the decision makers use. The decision makers are not imposed to use a predefined scale to ensure a constraint. Therefore, a decision-making model constructed with q-ROFs has always an edge on the flexibility compared to the models with IFS and PFS. The application steps of the proposed approach are as:

Step 1: The alternatives $\left(A_{i}, i=1,2, \ldots, m\right)$ and the evaluation attributes $\left(C_{j}, j=1,2, \ldots, n\right)$ of the MADM problem are determined. According to linguistic terms that the decision makers use, q-ROF scales are constructed and the minimum $q$ is calculated, satisfying the constraint on the strength of commitment.

Step 2: The q-ROF decision matrix, which contains the evaluation of the alternatives with respect to decision attributes, and the q-ROF weight vector of decision attributes are constructed as 


$$
\begin{gathered}
D=\left[\begin{array}{cccc}
O_{11} & O_{12} & \cdots & O_{1 n} \\
O_{21} & O_{22} & \cdots & O_{2 n} \\
\vdots & \vdots & \ddots & \vdots \\
O_{m 1} & O_{m 2} & \cdots & O_{m n}
\end{array}\right] \\
i=1,2, \ldots m ; j=1,2, \ldots, n \\
W=\left(W_{1}, W_{2}, \ldots, W_{n}\right) \quad j=1,2, \ldots, n
\end{gathered}
$$

where $O_{i j}$ and $w_{j}$ are both q-ROFs that are represented as $O_{i j}=\left\langle M_{O_{i j}}, N_{O_{i j}}\right\rangle_{q}$ and $w_{j}=\left\langle M_{w_{j}}, N_{w_{j}}\right\rangle_{q}$.

Step 3: The weighted normalized q-ROF decision matrix $V=\left[V_{i j}\right]_{m x n}$ is calculated using Eq. (9), as

$$
V_{i j}=O_{i j} \otimes W_{j} .
$$

Step 4: Define the ideal solution $\left(A^{*}\right)=\left(V_{1}^{*}, V_{2}^{*}, \ldots, V_{n}^{*}\right)$, and the anti-ideal solution $\left(A^{-}\right)=\left(V_{1}^{-}, V_{2}^{-}, \ldots, V_{n}^{-}\right)$, where $V_{j}^{*}=$ $\langle 1,0\rangle$ and $V_{j}^{-}=\langle 0,1\rangle$ for $j=1,2, \ldots, n$.

Step 5: Compute the distances from ideal solution and antiideal solution $\left(D_{i}^{*}\right.$ and $D_{i}^{-}$, respectively) for each alternative employing the following Eq. (15) [25] with two q-ROFS $O_{1}=\left\langle M_{1}, N_{1}\right\rangle_{q}$ and $O_{2}=\left\langle M_{2}, N_{2}\right\rangle_{q}$.

$D\left(O_{1}, O_{2}\right)=\sqrt{\frac{1}{2}\left[\left(M_{1}-M_{2}\right)^{2}+\left(N_{1}-N_{2}\right)^{2}+\left(H_{1}-H_{2}\right)^{2}\right]}$

Step 6: Compute the closeness coefficient $\left(C C_{i}\right)$ of each alternative as follows:

$$
C C_{i}=D_{i}^{-} /\left(D_{i}^{*}+D_{i}^{-}\right) \quad, i=1,2, \ldots, m
$$

Step 7: Rank the alternatives with respect to $C C_{i}$ values in descending order. The alternative that has the highest $C C_{i}$ value is identified as the best performing alternative. The flowchart of the proposed method is given in Fig.2.

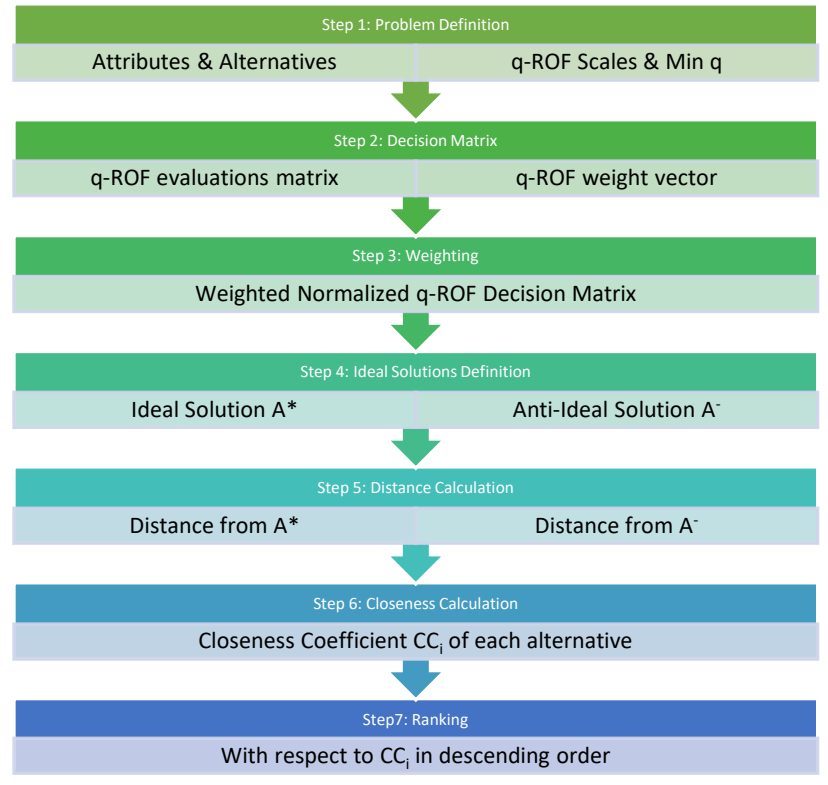

Figure 2. Flowchart of the proposed method

\section{CASE STUDY OF LENGTH OF HOSPITAL STAY PREDICTION IN COPD}

\subsection{Numerical Application}

Chronic Obstructive Pulmonary Disease (COPD) is caused by airflow limitations, diverse problems in airways and in other components of the lung. The disease is not curable; however, the symptoms can be eased. An acute exacerbation of COPD is defined as sudden development of respiratory symptoms with malfunctioning of airways. Acute exacerbations frequently result in hospital admission of patients. Predicting the length of hospital stay of inpatients is significant for an effective hospital management. The information of which patient will be discharged earlier than the others simplifies scheduling of the patient chambers and beds which are very limited in state hospitals, and therefore reduces operating costs of the hospital.

The case study is conducted in Yedikule Chest Diseases and Thoracic Surgery Training \& Research Hospital, which is located in Istanbul / Turkey, with 10 patients that applied to the hospital with an acute exacerbation. Two experienced physicians of the hospital, Assoc. Prof. Esin Tuncay MD, and Assoc. Prof. Gülfidan Aras MD contributed to the application with the purpose of predicting the discharging order of the patients in their clinic of 10 chambers. The application is terminated after all of the 10 patients are discharged, hence the actual ranking is known.

The decision of discharge is made by physicians and it depends on clinical condition of the patient. The problem can be observed as an MADM problem. The alternatives are 10 current inpatients of the clinic and the attributes are the clinical findings, which are observed by the physicians before discharging a COPD patient. After the interviews, seven attributes are determined for the problem:

1) Need of NIMV in hospital (NIMV): The amount of time that the patient will need Non-Invasive Mechanical Ventilation machine during the hospital stay, according to the physician.

2) Albumin (ALB): Albumin level in patient's blood. A result of the blood test, interpreted by the physician.

3) Amount of previous hospitalizations (HOSP): The amount of previous hospitalizations of the patient by COPD related causes.

4) White blood cell count (WBC): White blood cell count in patient's blood. A result of the blood test, interpreted by the physician.

5) Total protein (TOT.PROT): Total protein level in patient's blood. A result of the blood test, interpreted by the physician.

6) Oxygen (O2): Amount of oxygen in the blood. A result of the blood gas test, interpreted by the physician.

7) Charlson's Comorbidity Index (CCI): The degree of comorbid conditions which may have an influence on mortality of the patient according to Charlson's Comorbidity Index (CCI) [26]. 
The decision makers are asked to evaluate the alternatives (patient's clinic condition) with respect to attributes by reaching the consensus. For the evaluation, they determined their linguistic term set using the advantage of maximum flexibility provided by q-ROFs. Three linguistic term sets are identified:

- Evaluation of alternatives: A= [Very Poor, Poor, Fair, Good, Very Good]

- Hesitation degrees: B= [Very Low, Low, Medium, High, Very High]

- Attribute weights: $\mathrm{C}=$ [Very Ineffective, Ineffective, Medium, Effective, Very Effective]

Since the decision makers have ten or more years of professional experience in their field, the maximum hesitation degree is determined as 0.5 . In order to minimize vagueness, $\mathrm{q}$ is calculated as 3 , which is the smallest number satisfying the q-ROF constraint given in Eq. (4). Alternative evaluation scale of q-ROFs and attribute weighting scale of q-ROFs are constructed as given in Table 1 and Table 2.

Decision makers evaluated the alternatives with respect to attributes using the linguistic term set of Table 1 and then they determined the weights of attributes using the linguistic term set of Table 2. The linguistic data of the problem with attribute weights are given in Table 3. For example, Patient 1 is "Very Good" with respect to NIMV attribute and the decision makers have "Very Low" hesitation on this information.

Table 1. Alternative evaluation scale of q-ROFs

\begin{tabular}{cccc|cccc|cccc|cccccc}
\hline & \multicolumn{1}{c}{ Very Low Hesitation } & \multicolumn{4}{c|}{ Low Hesitation } & \multicolumn{4}{c}{ Medium Hesitation } & \multicolumn{4}{c}{ High Hesitation } & \multicolumn{3}{c}{ Very High Hesitation } \\
\hline & $\mathrm{M}$ & $\mathrm{N}$ & $\mathrm{H}$ & $\mathrm{M}$ & $\mathrm{N}$ & $\mathrm{H}$ & $\mathrm{M}$ & $\mathrm{N}$ & $\mathrm{H}$ & $\mathrm{M}$ & $\mathrm{N}$ & $\mathrm{H}$ & $\mathrm{M}$ & $\mathrm{N}$ & $\mathrm{H}$ \\
\hline Very Good & 0.9 & 0.6463 & 0.1 & 0.9 & 0.6407 & 0.2 & 0.9 & 0.6249 & 0.3 & 0.9 & 0.5915 & 0.4 & 0.9 & 0.5266 & 0.5 \\
Good & 0.7 & 0.8689 & 0.1 & 0.7 & 0.8658 & 0.2 & 0.7 & 0.8573 & 0.3 & 0.7 & 0.8401 & 0.4 & 0.7 & 0.8103 & 0.5 \\
Fair & 0.5 & 0.9561 & 0.1 & 0.5 & 0.9535 & 0.2 & 0.5 & 0.9465 & 0.3 & 0.5 & 0.9326 & 0.4 & 0.5 & 0.9086 & 0.5 \\
Poor & 0.3 & 0.9906 & 0.1 & 0.3 & 0.9882 & 0.2 & 0.3 & 0.9817 & 0.3 & 0.3 & 0.9687 & 0.4 & 0.3 & 0.9465 & 0.5 \\
Very Poor & 0.1 & 0.9993 & 0.1 & 0.1 & 0.9970 & 0.2 & 0.1 & 0.9906 & 0.3 & 0.1 & 0.9778 & 0.4 & 0.1 & 0.9561 & 0.5 \\
\hline
\end{tabular}

Table 2. Attribute weighting scale of q-ROFs

\begin{tabular}{cccc}
\hline & $\mathrm{M}$ & $\mathrm{N}$ & $\mathrm{H}$ \\
\hline Very Effective & 0.9 & 0.6471 & 0 \\
Effective & 0.7 & 0.8658 & 0.2 \\
Medium Effective & 0.5 & 0.9326 & 0.4 \\
Ineffective & 0.3 & 0.9882 & 0.2 \\
Very Ineffective & 0.1 & 0.9997 & 0 \\
\hline
\end{tabular}

Table 3. Linguistic data of the problem

\begin{tabular}{|c|c|c|c|c|c|c|c|}
\hline & NIMV & ALB & HOSP & WBC & TOT.PROT & $\mathrm{O} 2$ & $\mathrm{CCI}$ \\
\hline Patient 1 & $\begin{array}{l}\text { Very Good, } \\
\text { Very Low }\end{array}$ & $\begin{array}{l}\text { Good, } \\
\text { Medium }\end{array}$ & $\begin{array}{l}\text { Good, Very } \\
\text { Low }\end{array}$ & Poor, High & $\begin{array}{l}\text { Very Good, } \\
\text { Low }\end{array}$ & $\begin{array}{l}\text { Poor, Very } \\
\text { Low }\end{array}$ & $\begin{array}{l}\text { Very Good, } \\
\text { Low }\end{array}$ \\
\hline Patient 2 & $\begin{array}{l}\text { Very Good, } \\
\text { Medium }\end{array}$ & Good, Low & $\begin{array}{l}\text { Very Good, } \\
\text { Low }\end{array}$ & Good, High & Good, High & Poor, Low & $\begin{array}{l}\text { Very Good, } \\
\text { Low }\end{array}$ \\
\hline Patient 3 & Good, Medium & $\begin{array}{c}\text { Fair, } \\
\text { Medium }\end{array}$ & $\begin{array}{l}\text { Very Good, } \\
\text { Very Low }\end{array}$ & $\begin{array}{c}\text { Good, Very } \\
\text { Low }\end{array}$ & $\begin{array}{l}\text { Good, } \\
\text { Medium }\end{array}$ & Fair, High & $\begin{array}{l}\text { Very Poor, } \\
\text { Very Low }\end{array}$ \\
\hline Patient 4 & Good, Low & $\begin{array}{c}\text { Fair, } \\
\text { Medium }\end{array}$ & Fair, Low & Good, Medium & $\begin{array}{l}\text { Good, } \\
\text { Medium }\end{array}$ & Fair, Low & $\begin{array}{l}\text { Very Good, } \\
\text { Low }\end{array}$ \\
\hline Patient 5 & $\begin{array}{l}\text { Very Good, } \\
\text { Medium }\end{array}$ & $\begin{array}{l}\text { Poor, } \\
\text { Medium }\end{array}$ & Poor, Low & Fair, Low & Good, Low & $\begin{array}{l}\text { Good, } \\
\text { Medium }\end{array}$ & Fair, Low \\
\hline Patient 6 & Fair, Low & $\begin{array}{l}\text { Poor, Very } \\
\text { Low }\end{array}$ & $\begin{array}{l}\text { Very Good, } \\
\text { Very Low }\end{array}$ & Fair, Medium & $\begin{array}{c}\text { Fair, } \\
\text { Medium }\end{array}$ & Fair, Medium & $\begin{array}{l}\text { Very Good, } \\
\text { Low }\end{array}$ \\
\hline Patient 7 & Fair, Very Low & Good, High & Fair, Low & Good, Low & $\begin{array}{l}\text { Very Good, } \\
\text { Low }\end{array}$ & $\begin{array}{l}\text { Very Good, } \\
\text { Low }\end{array}$ & Poor, Medium \\
\hline Patient 8 & Poor, Low & $\begin{array}{l}\text { Good, } \\
\text { Medium }\end{array}$ & Good, Low & Good, High & Good, High & Good, Low & $\begin{array}{l}\text { Very Good, } \\
\text { Low }\end{array}$ \\
\hline Patient 9 & Poor, Medium & $\begin{array}{c}\text { Good, Very } \\
\text { High }\end{array}$ & Poor, Low & Poor, High & Poor, Low & $\begin{array}{l}\text { Very Good, } \\
\text { Medium }\end{array}$ & Poor, Medium \\
\hline Patient 10 & $\begin{array}{l}\text { Very Poor, } \\
\text { Medium }\end{array}$ & $\begin{array}{l}\text { Poor, } \\
\text { Medium }\end{array}$ & Good, Medium & $\begin{array}{l}\text { Very Poor, } \\
\text { Very Low }\end{array}$ & Poor, Low & $\begin{array}{l}\text { Good, } \\
\text { Medium }\end{array}$ & Good, Medium \\
\hline $\begin{array}{l}\text { Attribute } \\
\text { Weights }\end{array}$ & Very Effective & Ineffective & $\begin{array}{l}\text { Medium } \\
\text { Effective }\end{array}$ & $\begin{array}{l}\text { Medium } \\
\text { Effective }\end{array}$ & Effective & $\begin{array}{c}\text { Very } \\
\text { Ineffective }\end{array}$ & Ineffective \\
\hline
\end{tabular}


Linguistic data collected from the experts are converted into orthopair fuzzy numbers according to scales of q-ROFs that are given in Tables 1 and 2. Orthopair fuzzy decision matrix, which show the scores of patients with respect to attributes as well as weights assigned to the attributes, are provided in Table 4.

The scores of patients regarding the attributes are weighted employing Eq. (9), hence weighted orthopair fuzzy decision matrix is obtained as in Table 5.
In order to calculate closeness coefficients, the distance to the ideal solution and the distance from the anti-ideal solution are computed using Eq.(15). The ideal solution is considered as $\langle 1,0\rangle$ whereas the anti-ideal solution is set to $\langle 0,1\rangle$. Afterwards, closeness coefficient values, which are to rank the alternatives in descending order, are calculated by Eq.(16). The ranking results with the distances and closeness coefficients are given Table 6 .

Table 4. Orthopair fuzzy decision matrix

\begin{tabular}{|c|c|c|c|c|c|c|c|c|c|c|c|c|}
\hline & \multicolumn{3}{|c|}{ NIMV } & \multicolumn{3}{|c|}{ ALB } & \multicolumn{3}{|c|}{ HOSP } & \multicolumn{3}{|c|}{ WBC } \\
\hline & $\mathrm{M}$ & $\mathrm{N}$ & $\mathrm{H}$ & $\mathrm{M}$ & $\mathrm{N}$ & $\mathrm{H}$ & $\mathrm{M}$ & $\mathrm{N}$ & $\mathrm{H}$ & $\mathrm{M}$ & $\mathrm{N}$ & $\mathrm{H}$ \\
\hline Patient 1 & 0.9 & 0.6463 & 0.1 & 0.7 & 0.8573 & 0.3 & 0.7 & 0.8689 & 0.1 & 0.3 & 0.9687 & 0.4 \\
\hline Patient 2 & 0.9 & 0.6249 & 0.3 & 0.7 & 0.8658 & 0.2 & 0.9 & 0.6407 & 0.2 & 0.7 & 0.8401 & 0.4 \\
\hline Patient 3 & 0.7 & 0.8573 & 0.3 & 0.5 & 0.9465 & 0.3 & 0.9 & 0.6463 & 0.1 & 0.7 & 0.8689 & 0.1 \\
\hline Patient 4 & 0.7 & 0.8658 & 0.2 & 0.5 & 0.9465 & 0.3 & 0.5 & 0.9535 & 0.2 & 0.7 & 0.8573 & 0.3 \\
\hline Patient 5 & 0.9 & 0.6249 & 0.3 & 0.3 & 0.9817 & 0.3 & 0.3 & 0.9882 & 0.2 & 0.5 & 0.9535 & 0.2 \\
\hline Patient 6 & 0.5 & 0.9535 & 0.2 & 0.3 & 0.9906 & 0.1 & 0.9 & 0.6463 & 0.1 & 0.5 & 0.9465 & 0.3 \\
\hline Patient 7 & 0.5 & 0.9561 & 0.1 & 0.7 & 0.8401 & 0.4 & 0.5 & 0.9535 & 0.2 & 0.7 & 0.8658 & 0.2 \\
\hline Patient 8 & 0.3 & 0.9882 & 0.2 & 0.7 & 0.8573 & 0.3 & 0.7 & 0.8658 & 0.2 & 0.7 & 0.8401 & 0.4 \\
\hline Patient 9 & 0.3 & 0.9817 & 0.3 & 0.7 & 0.8103 & 0.5 & 0.3 & 0.9882 & 0.2 & 0.3 & 0.9687 & 0.4 \\
\hline Patient 10 & 0.1 & 0.9906 & 0.3 & 0.3 & 0.9817 & 0.3 & 0.7 & 0.8573 & 0.3 & 0.1 & 0.9993 & 0.1 \\
\hline Weight & 0.9 & 0.6471 & 0 & 0.3 & 0.9882 & 0.2 & 0.5 & 0.9326 & 0.4 & 0.5 & 0.9326 & 0.4 \\
\hline
\end{tabular}

\begin{tabular}{c|ccc|ccc|ccc}
\hline & \multicolumn{3}{|c|}{ TOT. PROT } & \multicolumn{3}{c|}{ O2 } & \multicolumn{3}{c}{ CCI } \\
\hline & $\mathrm{M}$ & $\mathrm{N}$ & $\mathrm{H}$ & $\mathrm{M}$ & $\mathrm{N}$ & $\mathrm{H}$ & $\mathrm{M}$ & $\mathrm{N}$ & $\mathrm{H}$ \\
\hline Patient 1 & 0.9 & 0.6407 & 0.2 & 0.3 & 0.9906 & 0.1 & 0.9 & 0.6407 & 0.2 \\
Patient 2 & 0.7 & 0.8401 & 0.4 & 0.3 & 0.9882 & 0.2 & 0.9 & 0.6407 & 0.2 \\
Patient 3 & 0.7 & 0.8573 & 0.3 & 0.5 & 0.9326 & 0.4 & 0.1 & 0.9993 & 0.1 \\
Patient 4 & 0.7 & 0.8573 & 0.3 & 0.5 & 0.9535 & 0.2 & 0.9 & 0.6407 & 0.2 \\
Patient 5 & 0.7 & 0.8658 & 0.2 & 0.7 & 0.8573 & 0.3 & 0.5 & 0.9535 & 0.2 \\
Patient 6 & 0.5 & 0.9465 & 0.3 & 0.5 & 0.9465 & 0.3 & 0.9 & 0.6407 & 0.2 \\
Patient 7 & 0.9 & 0.6407 & 0.2 & 0.9 & 0.6407 & 0.2 & 0.3 & 0.9817 & 0.3 \\
Patient 8 & 0.7 & 0.8401 & 0.4 & 0.7 & 0.8658 & 0.2 & 0.9 & 0.6407 & 0.2 \\
Patient 9 & 0.3 & 0.9882 & 0.2 & 0.9 & 0.6249 & 0.3 & 0.3 & 0.9817 & 0.3 \\
Patient 10 & 0.3 & 0.9882 & 0.2 & 0.7 & 0.8573 & 0.3 & 0.7 & 0.8573 & 0.3 \\
\hline Weight & 0.7 & 0.8658 & 0.2 & 0.1 & 0.9997 & 0 & 0.3 & 0.9882 & 0.2 \\
\hline
\end{tabular}

Table 5. Weighted orthopair fuzzy decision matrix

\begin{tabular}{|c|c|c|c|c|c|c|c|c|c|c|c|c|}
\hline & \multicolumn{3}{|c|}{ NIMV } & \multicolumn{3}{|c|}{ ALB } & \multicolumn{3}{|c|}{ HOSP } & \multicolumn{3}{|c|}{ WBC } \\
\hline & M & $\mathrm{N}$ & $\mathrm{H}$ & M & $\mathrm{N}$ & $\mathrm{H}$ & M & $\mathrm{N}$ & $\mathrm{H}$ & $\mathrm{M}$ & $\mathrm{N}$ & $\mathrm{H}$ \\
\hline Patient 1 & 0.81 & 0.7763 & 0.09 & 0.21 & 0.9957 & 0.1545 & 0.35 & 0.9778 & 0.2808 & 0.15 & 0.9942 & 0.2400 \\
\hline Patient 2 & 0.81 & 0.7657 & 0.27 & 0.21 & 0.9959 & 0.1446 & 0.45 & 0.9512 & 0.3638 & 0.35 & 0.9737 & 0.3241 \\
\hline Patient 3 & 0.63 & 0.9005 & 0.27 & 0.15 & 0.9982 & 0.1248 & 0.45 & 0.9517 & 0.3605 & 0.35 & 0.9778 & 0.2808 \\
\hline Patient 4 & 0.63 & 0.9062 & 0.18 & 0.15 & 0.9982 & 0.1248 & 0.25 & 0.9915 & 0.2119 & 0.35 & 0.9761 & 0.3002 \\
\hline Patient 5 & 0.81 & 0.7657 & 0.27 & 0.09 & 0.9994 & 0.1051 & 0.15 & 0.9978 & 0.1480 & 0.25 & 0.9915 & 0.2119 \\
\hline Patient 6 & 0.45 & 0.9666 & 0.18 & 0.09 & 0.9997 & 0.0631 & 0.45 & 0.9517 & 0.3605 & 0.25 & 0.9903 & 0.2358 \\
\hline Patient 7 & 0.45 & 0.9684 & 0.09 & 0.21 & 0.9952 & 0.1708 & 0.25 & 0.9915 & 0.2119 & 0.35 & 0.9774 & 0.2863 \\
\hline Patient 8 & 0.27 & 0.9914 & 0.18 & 0.21 & 0.9957 & 0.1545 & 0.35 & 0.9774 & 0.2863 & 0.35 & 0.9737 & 0.3241 \\
\hline Patient 9 & 0.27 & 0.9867 & 0.27 & 0.21 & 0.9945 & 0.1924 & 0.15 & 0.9978 & 0.1480 & 0.15 & 0.9942 & 0.2400 \\
\hline Patient 10 & 0.09 & 0.9931 & 0.27 & 0.09 & 0.9994 & 0.1051 & 0.35 & 0.9761 & 0.3002 & 0.05 & 0.9999 & 0.0632 \\
\hline
\end{tabular}

\begin{tabular}{c|ccc|ccc|ccc}
\hline & \multicolumn{3}{|c|}{ TOT. PROT } & \multicolumn{3}{c|}{ O2 } & \multicolumn{3}{c}{ CCI } \\
\hline & $\mathrm{M}$ & $\mathrm{N}$ & $\mathrm{H}$ & $\mathrm{M}$ & $\mathrm{N}$ & $\mathrm{H}$ & $\mathrm{M}$ & $\mathrm{N}$ & $\mathrm{H}$ \\
\hline Patient 1 & 0.63 & 0.9050 & 0.2052 & 0.03 & 0.9999 & 0.01 & 0.27 & 0.9913 & 0.1828
\end{tabular}




\begin{tabular}{l|lll|lll|lll} 
Patient 2 & 0.49 & 0.9499 & 0.2932 & 0.03 & 0.9999 & 0.02 & 0.27 & 0.9913 & 0.1828 \\
Patient 3 & 0.49 & 0.9547 & 0.2303 & 0.05 & 0.9999 & 0.04 & 0.03 & 0.9999 & 0.0350 \\
Patient 4 & 0.49 & 0.9547 & 0.2303 & 0.05 & 0.9999 & 0.02 & 0.27 & 0.9913 & 0.1828 \\
Patient 5 & 0.49 & 0.9571 & 0.1771 & 0.07 & 0.9999 & 0.03 & 0.15 & 0.9984 & 0.1086 \\
Patient 6 & 0.35 & 0.9819 & 0.2188 & 0.05 & 0.9999 & 0.03 & 0.27 & 0.9913 & 0.1828 \\
Patient 7 & 0.63 & 0.9050 & 0.2052 & 0.09 & 0.9998 & 0.02 & 0.09 & 0.9994 & 0.1051 \\
Patient 8 & 0.49 & 0.9499 & 0.2932 & 0.07 & 0.9999 & 0.02 & 0.27 & 0.9913 & 0.1828 \\
Patient 9 & 0.21 & 0.9959 & 0.1446 & 0.09 & 0.9997 & 0.03 & 0.09 & 0.9994 & 0.1051 \\
Patient 10 & 0.21 & 0.9959 & 0.1446 & 0.07 & 0.9999 & 0.03 & 0.21 & 0.9957 & 0.1545 \\
\hline
\end{tabular}

Table 6. Ranking results

\begin{tabular}{lcccc}
\hline & $\mathrm{D}_{\mathrm{i}}^{*}$ & $\mathrm{D}_{\mathrm{i}}^{-}$ & $\mathrm{CC}_{\mathrm{i}}$ & Rank \\
\hline Patient 1 & 2.4579 & 0.8999 & 0.2680 & 2 \\
Patient 2 & 2.5132 & 0.9620 & 0.2768 & 1 \\
Patient 3 & 2.5447 & 0.8234 & 0.2445 & 3 \\
Patient 4 & 2.5187 & 0.7750 & 0.2353 & 5 \\
Patient 5 & 2.5074 & 0.7963 & 0.2410 & 4 \\
Patient 6 & 2.5654 & 0.7006 & 0.2145 & 8 \\
Patient 7 & 2.5067 & 0.7325 & 0.2261 & 6 \\
Patient 8 & 2.5792 & 0.7235 & 0.2191 & 7 \\
Patient 9 & 2.6532 & 0.4716 & 0.1509 & 10 \\
Patient 10 & 2.6599 & 0.4789 & 0.1526 & 9 \\
\hline
\end{tabular}

The application is terminated after all of the patients are discharged, with the aim of observing the performance of the proposed decision support system. The actual ranking and the ranking determined by OFTOPSIS method are compared by Spearman rank correlation coefficient in order to understand whether there is a positive relationship between the ranking results of the two approaches. Moreover, one can note that the two approaches yield similar set of rankings through Spearman's rank correlation coefficient, which is computed as 0.927. Thus, there is a strong positive correlation between the actual ranking and the ranking obtained by the proposed method.

\subsection{Comparison of the Results with Fuzzy TOPSIS}

In order to discuss the results of the proposed method, the same patient data is implemented again with the fuzzy TOPSIS (FTOPSIS) method. The most important difference between the two methods, during data collection from physicians, is the hesitation data. In FTOPSIS, decision makers cannot specify their hesitation degrees, they only evaluate alternatives with respect to the attributes. Hence, in this second application, the linguistic data in Table 3 is used without hesitation degrees. The scale of triangular fuzzy numbers is chosen as Very Good: $(0.75,1,1)$, Good: $(0.5$, $0.75,1)$, Fair: $(0.25,0.5,0.75)$, Poor: $(0,0.25,0.5)$, Very Poor: $(0,0,0.25)$ for evaluation of the alternatives and weighting of the attributes. The results of the FTOPSIS application are given in Table 7 .

The Spearman rank correlation coefficient of the results of FTOPSIS with the actual ranking is computed as 0.455 . There is a weak positive correlation with the actual ranking however, it is not significant.
Table 7. Ranking results of FTOPSIS

\begin{tabular}{ccccc}
\hline & $\mathrm{D}_{\mathrm{i}}^{*}$ & $\mathrm{D}_{\mathrm{i}}^{-}$ & $\mathrm{CC}_{\mathrm{i}}$ & $\mathrm{Rank}$ \\
\hline Patient 1 & 4.6618 & 0.3227 & 0.0682 & 2 \\
Patient 2 & 4.4960 & 0.3227 & 0.0707 & 1 \\
Patient 3 & 4.8463 & 0.0722 & 0.0146 & 10 \\
Patient 4 & 4.8318 & 0.3227 & 0.0653 & 3 \\
Patient 5 & 5.0135 & 0.2282 & 0.0442 & 7 \\
Patient 6 & 5.1350 & 0.3227 & 0.0616 & 5 \\
Patient 7 & 4.9574 & 0.1488 & 0.0292 & 8 \\
Patient 8 & 5.0528 & 0.3227 & 0.0621 & 4 \\
Patient 9 & 5.8951 & 0.1488 & 0.0246 & 9 \\
Patient 10 & 5.9255 & 0.3083 & 0.0508 & 6 \\
\hline
\end{tabular}

In fact, FTOPSIS is a powerful technique in handling the uncertainty and vagueness in MADM problems. In many application areas, it performs very well when there is no or little hesitation, but if decision makers have serious hesitations, they should be transferred to the model. For this reason, in this application OFTOPSIS performed better for the medical decision support system, where hesitations were high. OFTOPSIS can be applied instead of FTOPSIS when the hesitations of decision makers are too high to be neglected.

\subsection{Limitations of the Case Study and Proposed Method}

Although the proposed method has performed well in the sample application problem, its limitations should be discussed. First, the patient data is the case study is limited to ten patients, which is the number of patient rooms on one floor in one clinic of the hospital. For the generalization of the results, a wider population is needed. In addition, the subjectivity in the case study (decision maker bias) can be assessed by changing the decision makers. Second, the proposed method predicted well the patients' discharging order however, the complexity of the model is too high for physicians to do their own practice in the hospital and use the method as a decision support system. The model should be implemented by a modeler. To provide simplicity in the daily use, a web interface can be designed to overcome this limitation.

\section{CONCLUSIONS}

In medical decision-making, the contribution of physicians' experience and knowledge to the model brings advantages however, in the practical application it is quite problematic to reflect what the physicians have in mind to a mathematical 
structure. The uniqueness of each patient's case and the lack of information on patient's medical history and current condition increase the complexity of the problems and the hesitation level of decision makers.

In this study, OFTOPSIS method is developed and proposed for solving the MADM problems in medicine. OFTOPSIS is the extension of TOPSIS method with q-ROF, which is the most generalized version of nonstandard fuzzy sets. Its first application is conducted on the problem of length of hospital stay prediction of COPD patients who admitted to hospital with acute exacerbation. With the objective to find the discharging order of the ten inpatients of the clinic, seven attributes are determined: Need of NIMV in hospital, albumin, the amount of previous hospitalizations, white blood cell count, total protein, oxygen and Charlson's comorbidity index. The physicians first determined the linguistic term sets that they want to use and then evaluated each patient with respect to the attributes while stating their hesitation level. They also evaluated the weights of attributes. q-ROF scales for linguistic terms are constructed after the evaluations, using the benefit of adjustable strength of commitment constraint of q-ROFs. With q-ROF decision matrix and q-ROF weight matrix, the weighted normalized q-ROF decision matrix is calculated. The ideal and anti-ideal solutions are defined and the distances from ideal and antiideal solutions for each alternative are computed. The ranking order of the alternatives is determined according to the closeness coefficients.

The application is terminated after all of the patients are discharged. Spearman's rank correlation coefficient between the ranking determined by OFTOPSIS method and the actual ranking is calculated as 0.927 , which shows a strong positive correlation. The ranking determined by OFTOPSIS method is highly similar to the actual ranking, which shows the usefulness of OFTOPSIS method as a decision aid in this medical problem.

By providing maximum freedom and flexibility to the physicians, OFTOPSIS method has the advantage of compatibility in medical decision-making. Not only are the decision makers able to use their own linguistic term set, but also, they can state their hesitation degree on the information that they give. When compared to conventional TOPSIS that uses crisp data, OFTOPSIS includes expert opinion in the model and therefore reflects the experience of the physicians. In addition, when compared to other fuzzy and nonstandard fuzzy extensions of TOPSIS, OFTOPSIS offers more convenience and ease in practical application. In the comparison of the case study, OFTOPSIS outranked FTOPSIS in Spearman rank correlation with actual data.

The case study achieved to show the practicality of OFTOPSIS method as a decision support system in medical decision-making. The contributions of this study can be summarized as: (1) the novel OFTOPSIS method is proposed, (2) a medical decision support framework is constructed to predict the discharging order of COPD patients, (3) the applicability and the power of OFTOPSIS method in medical decision-making is stated. As future research directions, the OFTOPSIS method can be used in other medical problems and in social sciences where decision makers demand more flexibility. OFTOPSIS can be integrated with other MADM methods and it can be developed to construct more specific decision support systems.

\section{Acknowledgments}

The author is grateful to chest disease specialists Assoc. Prof. Esin Tuncay MD, and Assoc. Prof. Gülfidan Aras MD, who contributed with their valuable insight and expertise. This study is supported by Galatasaray University Research Fund, project 19.402.009.

\section{REFERENCES}

[1] L. Zadeh, "Fuzzy Sets," Information and Control, vol. 8, no. 3, pp. 338-353, 1965.

[2] K. T. Atanassov, "Intuitionistic Fuzzy-Sets," (in English), Fuzzy Sets and Systems, vol. 20, no. 1, pp. 87-96, Aug 1986.

[3] R. R. Yager and A. M. Abbasov, "Pythagorean membership grades, complex numbers, and decision making," International Journal of Intelligent Systems, vol. 28, no. 5, pp. 436-452, 2013.

[4] K. Atanassov, P. Vassilev, and R. Tcvetkov, "Intuitionistic fuzzy sets, measures and integrals," Prof. M. Drinov" Academic Publishing House, Sofia, 2013.

[5] R. R. Yager, "Generalized orthopair fuzzy sets," IEEE Transactions on Fuzzy Systems, vol. 25, no. 5, pp. 1222-1230, 2017.

[6] R. R. Yager and N. Alajlan, "Approximate reasoning with generalized orthopair fuzzy sets," Information Fusion, vol. 38, pp. 65-73, Nov 2017.

[7] B. P. Joshi, A. Singh, P. K. Bhatt, and K. S. Vaisla, "Interval valued q-rung orthopair fuzzy sets and their properties," Journal of Intelligent \& Fuzzy Systems, vol. 35, no. 5, pp. 5225-5230, 2018.

[8] X. D. Peng, J. G. Dai, and H. Garg, "Exponential operation and aggregation operator for q-rung orthopair fuzzy set and their decision-making method with a new score function," International Journal of Intelligent Systems, vol. 33, no. 11, pp. 2255-2282, Nov 2018.

[9] R. R. Yager, N. Alajlan, and Y. Bazi, "Aspects of generalized orthopair fuzzy sets," International Journal of Intelligent Systems, vol. 33, no. 11, pp. 2154-2174, Nov 2018.

[10]A. Habib, M. Akram, and A. Farooq, "q-Rung Orthopair Fuzzy Competition Graphs with Application in the Soil Ecosystem," Mathematics, vol. 7, no. 1, Jan 2019, Art. no. 91.

[11]W. S. Du, "Correlation and correlation coefficient of generalized orthopair fuzzy sets," International Journal of Intelligent Systems, vol. 34, no. 4, pp. 564-583, Apr 2019. [12]P. D. Liu and J. L. Liu, "Some q-Rung Orthopai Fuzzy Bonferroni Mean Operators and Their Application to Multi- 
Attribute Group Decision Making," International Journal of Intelligent Systems, vol. 33, no. 2, pp. 315-347, Feb 2018. [13]G. W. Wei, H. Gao, and Y. Wei, "Some q-rung orthopair fuzzy Heronian mean operators in multiple attribute decision making," International Journal of Intelligent Systems, vol. 33, no. 7, pp. 1426-1458, Jul 2018.

[14]P. D. Liu, S. M. Chen, P. Wang, and Ieee, The q-Rung Orthopair Fuzzy Power Maclaurin Symmetric Mean Operators (Proceedings of 2018 Tenth International Conference on Advanced Computational Intelligence). 2018, pp. 156-161.

[15]K. Y. Bai, X. M. Zhu, J. Wang, and R. T. Zhang, "Some Partitioned Maclaurin Symmetric Mean Based on q-Rung Orthopair Fuzzy Information for Dealing with MultiAttribute Group Decision Making," Symmetry-Basel, vol. 10, no. 9, Sep 2018, Art. no. 383.

[16]P. D. Liu and P. Wang, "Some q-Rung Orthopair Fuzzy Aggregation Operators and their Applications to MultipleAttribute Decision Making," International Journal of Intelligent Systems, vol. 33, no. 2, pp. 259-280, Feb 2018.

[17]Y. H. Huang and G. W. Wei, "TODIM method for interval-valued Pythagorean fuzzy multiple attribute decision making," International Journal of KnowledgeBased and Intelligent Engineering Systems, vol. 22, no. 4, pp. 249-259, 2018.

[18]W. S. Du, "Minkowski-type distance measures for generalized orthopair fuzzy sets," International Journal of Intelligent Systems, vol. 33, no. 4, pp. 802-817, Apr 2018.

[19]L. Li, R. T. Zhang, J. Wang, X. P. Shang, and K. Y. Bai, "A Novel Approach to Multi-Attribute Group DecisionMaking with q-Rung Picture Linguistic Information," Symmetry-Basel, vol. 10, no. 5, May 2018, Art. no. 172.
[20]J. Wang, H. Gao, G. W. Wei, and Y. Wei, "Methods for Multiple-Attribute Group Decision Making with q-Rung Interval-Valued Orthopair Fuzzy Information and Their Applications to the Selection of Green Suppliers," Symmetry-Basel, vol. 11, no. 1, Jan 2019, Art. no. 56. [21]G. W. Wei, C. Wei, J. Wang, H. Gao, and Y. Wei, "Some q-rung orthopair fuzzy maclaurin symmetric mean operators and their applications to potential evaluation of emerging technology commercialization," International Journal of Intelligent Systems, vol. 34, no. 1, pp. 50-81, Jan 2019.

[22]W. Yang and Y. F. Pang, "New q-rung orthopair fuzzy partitioned Bonferroni mean operators and their application in multiple attribute decision making," International Journal of Intelligent Systems, vol. 34, no. 3, pp. 439-476, Mar 2019. [23]C. L. Hwang and K. Yoon, Multiple attribute decision making : methods and applications : a state-of-the-art survey (Lecture Notes in Economics and Mathematical Systems, no. 186). Berlin ; New York: Springer-Verlag, 1981, pp. x, 259 p.

[24]P. Liu and P. Wang, "Some q-rung orthopair fuzzy aggregation operators and their applications to multipleattribute decision making," International Journal of Intelligent Systems, vol. 33, no. 2, pp. 259-280, 2018.

[25]D. F. Li, "Extension of the LINMAP for multiattribute decision making under Atanassov's intuitionistic fuzzy environment," (in English), Fuzzy Optimization and Decision Making, vol. 7, no. 1, pp. 17-34, Mar 2008.

[26]M. E. Charlson, P. Pompei, K. L. Ales, and C. R. MacKenzie, "A new method of classifying prognostic comorbidity in longitudinal studies: Development and validation," Journal of Chronic Diseases, vol. 40, no. 5, pp. 373-383, 1987/01/01/ 1987. 